DOI https://doi.org/10.30525/978-9934-26-073-5-1-70

\title{
SEMANTIC STRUCTURE OF DENUMERAL LEXICAL UNITS IN ENGLISH INTERNET MEDIA
}

\author{
Serhiienko A. S. \\ Postgraduate student t the Department of Germanic Philology \\ Sumy State University \\ Sumy, Ukraine
}

Language unit study should be based on its profound cognition in terms of language system and functioning. The relevance of this research is determined by functional linguistics, on the one hand, and interest in the study of denumeral lexical units, on the other.

The object of studying is a denumeral unit as a secondary formation that implements the general categorical seme of quantity, forming a lexical range, where the formal center is the root of a numeral, and the semantic center is the seme of a number. The subject of studying is the identification of the semantic structure of denumerals as a part of speech within the English Internet media.

English numerals are an independent, open range of significant numeral words, which have specific semantic, syntactic and derivational features. The leading place of numerals in the lexical-semantic field of quantity is explicated by their rigoristic correlation with the natural range of numbers, the ability to replace counting words, polyfunctionality, polymodality and multi-aspect character of usage. Modern English numerals have features of informativeness, dynamism, terminology, correlation with units of the lexical-semantic field of quantity, regular semantic shifts, and multi-valence of word-formation. In the context, numerals modify the syntactic, pragmatic, morphological, epidigmatic functions, the latter of which is objectified by the existing paradigm of denumerals formed by macrosystem models. The paradigmatic multiplier and semantic concept of denumeral units determine their semantic structure as the part of speech.

Substantive origin of numerals is distant in time and illusive. Interpretation of numbers is a major problem of linguistic quantification. Number reflects the quantitative aspects of the world in language. Quantitative meanings include the whole corpus of content words - nouns, adjectives, verbs, pronouns. According to their origin, numerals inextricably integrated with the notation of objects, having the meaning of substantivity and quantitativity [2]. Later, the numerals lost their substantivity but retained their seme of numerality. Numerals indicate the results of human cognitive activity. 
Denumeral nouns are in the centre of considering semantic structure of denumerals as part-of-speech units. Nominalized numerals have formal features of nouns that reflect the retrospective formation of numerals, having substantial origin. [1]. Denumeral nouns acquire the plural suffix -s, an article, compatibility with an adjective. Denumeral nouns are mainly formed by conversion and affixation.

According to their semantic structure, the following types of denumeral nouns are identified: [2]

1) Denumerals with the meaning of a person (thing) or a group of people (things): In order to concentrate on the one you must, by default, ignore many others (www.healthline.com).

2) Denumerals with the meaning of temporal periods (terms): The rate of unemployment throughout the nineties exhibited a generally fluctuating trend (core.ac.uk).

3) Denumerals with the meaning of various phenomena, eg. English «ten» can indicate: 1) the size of clothing or footwear, 2) the amount of coal (40-50 tonnes), 3) a boat for ten people, 4) age, 5) time, 6) playing cards, etc.: 67\% of American women wear the US fourteen or above, and most stores don't carry those numbers, however arbitrary they may be (time.com).

4) Denumerals with the meaning of grades: Seven out of ten hashtags on Instagram are branded (secretsushi.com).

5) Lexical units with converted numerals: Convertible, four-by-four, brand new (news.jardinemotors.co.uk).

6) Denumeral nouns that serve as nominative means of measure: There are thousands of them on our beaches (forum.duolingo.com).

Denumeral nouns have the syntactic function of the subject and the object: Child Tax Credits if you're responsible for the one or more - how much you get, tax credit calculator, eligibility, claim tax credits (gov.uk).

Denumeral pronouns constitute a specific group. Pronoun is a part of speech that indicates objects, signs, or quantities without naming them. Pronouns perform the function of substitution of nouns [1]. The autonomy of the numeral is in the actualization of its inherent numerical content, while the meaning of the pronoun is constitutively oriented and depends on the semantics of substituted words.

The presence of a constant number seme distinguishes numerals from both pronouns and other words. Numerals semantize numerality - their differential aspect, which is regularly realized in combination with nouns or without them - in elliptical constructions: What Should You Do If You Come in Contact With Someone Who's Infected With COVID-19? (health.clevelandclinic.org) 
The main ways of denumeral pronouns formation are conversion (one), affixation (none), and composition (anyone, everyone, someone):

Denumeral pronouns are divided into the following groups:

1) Denumeral reciprocal pronouns: Lawyers in South Dakota marijuana battle turn up heat against one another (keloland.com).

2) Denumeral pronouns of negation, namely none and no one: The Government of No One (akpress.org).

3) Indefinite denumeral pronouns, such as anyone, one and someone: And anyone attending their GP or hospital, should let the treating clinician know the details of the vaccine they received, and the date they've received the doses. (health.gov.au).

4) Denumeral everyone functions as a general indefinite pronoun: This radio ad, in Hindi, explains that everyone in Australia is entitled to free and voluntary COVID-19 vaccines. (health.gov.au).

Denumeral pronouns perform the functions of the subject or an object in the sentence: No One Eats Alone (islandpress.org).

Denumeral adjectives explicate characteristics of an object, event or other characteristic expressed by the nominal part of speech. An adjective denotes either a qualitative feature of an object, beyond its relation to other objects, events and characteristics, or a relative feature.

Adjectives semantically tend to nouns. An adjective functions as a noun definition, forming an attributive construction, or as a predicate or a part of a predicate, combining with a noun through an auxiliary verb. The classification of adjectives is heterogeneous due to their ontology and the meanings of referents. In contrast to adjectives, numerals express the quantitative representation of referents, denoting the results of cognitive activity. Denumeral adjectives are formed in two ways, namely affixation (only, fourth, fifth) and composition (seven-year-old). Ordinal numbers are included in the intersection of functional-semantic fields of quantitativity and qualitativity [2]. Ordinal words occur from numerals, but are characterized by a specific semantic structure that has inherent features of the adjectives, i.e. they reflect the qualitative characteristics of the subject through the correlation with the number: What is the Fourth Estate, why is the press called the fourth estate and where does the term come from? (thesun.co.uk)

The study shows the systemic properties of denumerals, which in artistic discourse acquire a wide spectrum of functional characteristics, i. e. the degree of applicability, implementation of the form-changing paradigm, lexical and grammatical compatibility, communicative purpose, pragmatic content, etc. The paradigmatics of denumerals determines their semantic structure. 
Scalar adherence of denumerals and numerals appears due to their correlation to lexical-semantic field of quantity, that is marked by definitions of discrete referents, the ability of dequantification, phraseologization and desemantization, up to word-creation. Differences between denumerals and numeral words are in modifications of formal structures, semantic deviations, word formation vectors, aspects of object semantisation, discreteness and correlation with number denotation.

The theoretical significance of this article contains in the expansion of the ideas about the ontological, cognitive and linguistic nature of denumerals, their role in the linguistic pattern of the world.

\title{
References:
}

1. Shvachko S. Polyfunctionality of the English Quantitative Words/ Journal of Education Culture and Society. 2013. № 2. P. 208-214.

2. Medvid O. System and Functional Properties of Quantitative Units, (Sistemno-functsionalnyie osobennosti kvantitativnukh edinits). Kharkiv, 2001. URL: http:www.lib.ua-ru.net/inode/5859.html

DOI https://doi.org/10.30525/978-9934-26-073-5-1-71

\section{СПОСОБИ УТВОРЕННЯ НЕОЛОГІЗМІВ, ЯКІ ВИКОРИСТОВУЮТЬСЯ ПРИ ВИСВІТЛЕННІ ПОДІЙ, ПОВ'ЯЗАНИХ ІЗ ПАНДЕМІЄЮ COVID-19}

\author{
Сивак А. О. \\ викладач англійської мови кафедри латинської та іноземних мов \\ Львівського начіонального медичного університету \\ імені Данила Галищького \\ м. Львів, Україна
}

Словниковий запас англійської мови стрімко розвивається за рахунок іншомовних запозичень, утворення неологізмів, появи нових значень слів, що вже використовуються. Засоби масової інформації, а саме: телебачення, Інтернет, соціальні мережі - дали змогу виокремити лексику, до якої найчастіше вдаються автори при висвітленні подій, пов'язаних із пандемією COVID-19. Вивчаючи статті, програми, дописи, результати досліджень університетів, пов'язаних із карантином, локдауном, захворюваністю та вакцинацією, ми не можемо не звернути увагу на те, що 2019 та 2020 роки збагатили англійську мову 